\title{
Hubungan Pengetahuan Dan Persepsi Dengan Kunjungan K1 Di Puskesmas Tikung Kabupaten Lamongan
}

\author{
Lilik Darwati \\ Program Studi Diploma III Kebidanan Universitas Islam Lamongan \\ Email: lilikdarwati@unisla.ac.id
}

\begin{abstract}
ABSTRAK
Pelayanan antenatal care terutama kunjungan K1 dilakukan pada usia kehamilan sebelum usia kehamilan 14 minggu. Namun di Desa guminingrejo dan Desa bangkalan pule kunjungan K1 sering kali terabaikan, hal ini kemungkinan berkaitan dengan pengetahuan dan persepsi ibu hamil yang kurang.

Desain penelitian ini menggunakan Analitik (Cross sectional), Populasinya ibu hamil berjumlah 39 orang dan sampelnya ibu hamil berjumlah 35 orang yang diambil menggunakan teknik consecutive sampling. Variabel yang diteliti adalah pengetahuan, persepsi dan kunjungan K1. Instrumennya menggunakan kuesioner dan buku KIA. Analisis data menggunakan uji spearman rank pada tingkat kesalahan $(\alpha)=0,05$.

Hasil penelitian menunjukkan bahwa lebih dari sebagian besar ibu hamil memiliki pengetahuan cukup 24 ibu hamil $(68,6 \%)$ dan sebagian besar 28 ibu hamil $(80,0 \%)$ memiliki persepsi positif dan sebagian besar 29 ibu hamil (82,9\%) melakukan kunjungan K1. Berdasarkan hasil uji spearman rank didapatkan nilai koefesien korelasi $0,000(\mathrm{p}<0,005)$ artinya ada hubungan pengetahuan dengan kunjungan K1 dan nilai koefesien korelasi 0,001 $(\mathrm{p}<0,005)$ artinya ada hubungan persepsi dengan kunjungan K1 pada ibu hamil.

Berdasarkan hasil penelitian ini maka Health Education sangat diperlukan bagi ibu hamil untuk mengetahui pentingnya kunjungan pertama atau kunjungan K1 bagi ibu hamil akan manfaatnya melakukan kunjungan $\mathrm{K} 1$.
\end{abstract}

Kata Kunci : pengetahuan, persepsi, ibu hamil, Kunjungan K1

\begin{abstract}
Antenatal care services, especially K1 visits, are performed at the gestational age before 14 weeks' gestation. However, in the community K1 visits are often neglected, this is likely to be related to a decrease in knowledge and perceptions of pregnant women who are lacking. This study aims to determine the relationship of knowledge and perceptions with K1 Dipukesmas Kedungpring visit Kedungpring Subdistrict, Lamongan Regency. The design of this study uses Cross-sectional Analytic with consecutive sampling approach. The sample of pregnant women totaling 35 people was taken using the consecutive sampling technique. The instrument uses KIA questionnaires and books. Data analysis using Spearman rank test with the help of SPSS version 16. The results of this study indicate that there is a relationship between knowledge and perception with $K 1$ visits. Based on the results of the Spearman rank test the value of correlation coefficient was 0.730 with a significance of $0.01(p<0.005)$ meaning that there was a relationship of knowledge with visit $K 1$ and the correlation coefficient value of 0.531 with a significant 0.05 ( $p<0.005)$. pregnant mother. Based on the results of this study, Health
\end{abstract}


Education is very necessary for pregnant women to know the importance of the first visit or K1 visit for pregnant women to benefit from K1 visits.

\section{Keywords: Knowledge, Perception of Pregnant Women, Visit KI}

\section{PENDAHULUAN}

Pelayanan natenatal merupakan pelayanan yang diterima wanita selama kehamilan dan sangat penting dalam membantu memastikan bahwa ibu dan janin selamat dalam kehamilan (mufdillah,2009). Antenatal care bertujuan mempersiapkan ibu hamil, fisik, psikologis dan sosial dalam menghadapi masa kehamilan, persalinan, nifas dan masa menyusui serta mengupayakan bayi yang dilahirkan sehat, kesiapan menghadapi komplikasi dalam kehamilan dan menanggulanginya, sehingga sedini mungkin jika ada penyimpangan atau komplikasi selama hamil dapat ditangani (Saifuddin AB, 2009). Setiap kehamilan dalam perkembanganya mempunyai resiko mengalami penyulit atau komplikasi. Oleh karena itu , pelayanan antenatal yang berkualitas. (Depkes, 2010:6).

K1 Merupakan kunjungan ibu hamil yang pertama kali pada masa kehamilan K1 dibagi menjadi 2 yaitu K! Murni dan K1 akses. K1Murni merupakan kontak pertama ibu hamil dengan petugas kesehatan untuk mendapatkan pemeriksaan kesehatan dan pelayanan kesehatan trimester I dimana usia kehamilan 1 sampai 12 minggu atau disebut juga dengan kunjungan $\mathrm{K} 1$, sedangkan $\mathrm{K} 1$ akses merupakan kontak pertama ibu hamil dengan tenaga kesehatan tanpa melihat umur kehamilan. Cakupan $\mathrm{K} 1$ atau juga disebut akses pelayanan kesehatan ibu hamil merupakan gambaran besaran ibu hamil yang telah melakukan kunjungan pertama kesarana kesehatan untuk mendapatkan palyanan antenatal.

Kesenjangan antara cakupan K1 besar, yang berarti masih banyak ibu hamil yang telah melakukan kunungan pertama pelayanan antenatal tidak meneruskan kunjungan sehingga kehamilannya lepas dari pemantauan petugas kesehatan.
Kondisi tersebut membuka peluang terjadinya kematian ibu dan bayi yang dikandungnya. Kondisi tersebut harus diantisipasi dengan meningkatkan penyuluhan ke masyarakat serta melakukan komunikasi edukasi yang intensif kepada ibu hamil dan keluarganya agar memeriksakan kehamilannya sesuai standart (profil kesehatan). untuk menggambarkan akses ibu hamil terhadap pelayanan antenatal K1 (akses/kontak pertama) dan K4 (lengkap) dengan tenaga kesehatan yang mempunyai kompetensi kebidanan. Secara nasional angka cakupan pelayanan antenatal seat ini sudah tinggi, K1 mencapai $94,24 \%$ dan K4 84,36\% Walaupun demikian, masih terdapat disparitas antar propinsi dan antar kabupaten atau kota yang variasinya cukup besar cakupan K1 di Jawa Timur yaitu 74,6\% masih di bawah target MDGS 2015 yaitu $90 \%$ dan belum ada satupun propinsi yang mencapai target MDGs tersebut (Kemenkes, 2010). Sedangkan data terakhir dilamongan pada tahun 2016 ibu hamil berjumlah 17,873 dan yang melakukan kunjungan K1 berjumlah 17, 865 (94,9\%).

Selanjutnya, berdasarkan hasil survey awal yang dilakukan peneliti pada tanggal 15 januari 2019 di Puskesmas Tikung jumlah keseluruhan ibu hamil dari seluruh desa berjumlah 346 sedangkan kunjungan K1 berjumlah 298 (86\%). Berdasarkan data tersebut diketahui kunjungan K1 pada puskesmas Tikung masih belum sesuai target sasaran yang diharapkan dipukesmas Tikung dari target nasional berjumlah $(92,2 \%)$.

Menurut Lawrence Green dalam Notoatmodjo (2010), perilaku seseorang atau masyarakat tentang kesehatan ditentukan oleh pengetahuan, sikap, kepercayaan, tradisi, dan atau masyarakat bersangkutan. Disamping itu, ketersediaan 
fasilitas, sikap, dan perilaku para petugas kesehatan juga akan mendukung dan memperkuatan terbentuknya perilaku. Seorang ibu hamil yang tidak mau memeriksan kehamilan bagi ibu dan janin yang dikandung. Tetapi barangkali juga karena rumahnya jauh dari puskesmas tempat memeriksakan kehamilannya atau peralatan yang tidak lengkap. Sebab lain mungkin karena para petugas kesehatan atau tokoh masyarakat lain disekitarnya tidak pernah memberikan contoh / penyuluhan tentng pentingnya pemeriksaan kehamilan. Perilaku mencakup 3 domain, yakni: pengetahuan (knowledge), sikap (attitude) dan tindakan atau praktik (health knowledge).

Pengawasan antenatal memberikan manfaat dengan ditemukannya berbagai kelainan yang menyertai kehamilan secara dini, sehingga dapat diperhitungkan dan dipersiapkan langkah - langkah pertolongan persalinannya. diketahui bahwa janin dalam rahim dan ibunya merupakan satu kesatuan yang saling mempengaruhi, sehingga kesehatan ibu yang optimal akan meningkatkan kesehatan, pertumbuhan, dan perkembangan janin. Ibu hamil dianjurkan untuk melakukan pengawasan antenatal sebanyak 4 kali, yaitu pada setiap trimester sedangkan trimester terakhir sebaanyak 2 kali (ida bagus gede manuaba, 2010). Dampak apabila ibu tidak melakukan kunjungan $\mathrm{K} 1$ adalah kurangnya informasi ibu hamil tentang perawatan kehamilan yang benar, tidak terdeteksinya pertumbuhan dan perkembangan janin serta kesehatan ibu, tidak terdeteksinya tanda bahaya kehamilan secara dini. (Marmi, 2011).

Untuk meningkatkan kunjungan kehamilan melalui penyampaian informasi secara tepat dalam bentuk iklan layanan masyarakat yang membahas mengenai antenatal care menjadi sangat dibutuhkan sebagai solusi untuk memberikan pengetahuan yang dapat meningkatkan kesadaran ibu hamil terhadap antenatal care. Menurut Pujiyanto (2013) informasi layanan masyarakat adalah proses penyampaian informasi yang bersifat mendidik melalui media periklanan agar pengetahuannya bertambah, menumbuhkan kesadaran sikap dan perubahan perilaku masyarakat terhadap masalah yang disampaikan, serta mendapatkan citra yang baik dimata masyarakat. Oleh karena itu, penulis sangat terdorong untuk merancang iklan layanan masyarakat untuk meningkatkan kesadaran ibu hamil terhadap antenatal care yang dapat mendeteksi dini komplikasi kehamilan yang menjadi penyebab kematian ibu.

Berdasarkan latar belakang tersebut maka peneliti tertarik untuk melakukan penelitian tentang “ Hubungan Pengetahuan dan Persepsi dengan Kunjungan K1 di Puskesmas Tikung Kabupaten Lamongan Tahun 2019

\section{METODE PENELITIAN}

Desain yang digunakan dalam penelitian ini adalah penelitian analitik dengan metode pendekatan cross sectional. Dengan populasi sejumlah 39 ibu hamil. Pengambilan sampel menggunakan teknik consecutive sampling dengan kreteria inklusi dalam penelitian ini adalah: 1)Ibu hamil diusia $\geq 14$ minggu dan kreteria ekslusi dalam penelitian ini adalah: 1) Ibu hamil di usia $\leq 14$ minggu. Menggunakan metode wawancara dan observasi dengan total 35 responden. Dengan menggunakan lembar kuesioner pengolahan dan analisis data dengan Esiting, Coding, Scoring, Tabulating, uji spearmen rank. Jenis instrumen yang digunakan dalam mendapat data variabel dependen (antenatal care (K1)), peneliti menggunakan observasi rekam medis dan variabel independen (Pengetahuan dan Persepsi), peneliti menggunakan lembar kuesioner. 


\section{HASIL PENELITIAN}

\section{Data Umum}

1) Karakteristik Lansia

\begin{tabular}{ccc}
\hline Umur & Jumlah & \% \\
\hline 20-35 tahun & 29 & 82,8 \\
$>35$ tahun & 6 & 17,1 \\
\hline Pendidikan & Jumlah & \% \\
\hline SMA & 30 & 85,7 \\
PT & 5 & 14,3 \\
& & \\
\hline Pekerjan & Jumlah & \% \\
\hline PNS & 3 & 8,6 \\
Swasta & 16 & 47,5 \\
IRT & 16 & 47,5 \\
\hline Usia Kehamilan & Jumlah & \% \\
\hline 13-27 & 23 & 65,7 \\
28-40 & 12 & 34,3 \\
& & \\
\hline Paritas & Jumlah & \% \\
\hline Primigravida & 5 & 9,1 \\
Multigravida & 30 & 80,9 \\
\hline & &
\end{tabular}

Dari tabel di atas menunjukan bahwa sebagian ibu hamil berjumlah 35 orang $(82,8 \%)$ berumur $20-35$ tahun, sebagian besar ibu hamil sebanyak 30 orang $(85,7 \%)$ responden berpendidikan SMA, sebagian ibu hamil 16 orang $(45,7 \%)$ sebagai IRT dan Swasta, sebagian ibu hamil sebanyak 23 orang $(65,7 \%)$ berusia kehamilan 13-27 minggu, sebagian besar ibu hamil sebanyak 30 orang $(80,9 \%)$ kehamilan anak ke 2.

\section{Data Khusus}

1) Pengetahuan responden

Tabel 1 Distribusi tentang Pengetahuan Ibu Hamil Di Wilayah Kerja Puskesmas Tikung Tahun 2019.

\begin{tabular}{lcc}
\hline Pengetahuan & Jumlah & $\mathbf{( \% )}$ \\
\hline Kurang & 5 & 14,3 \\
Cukup & 24 & 68,6 \\
Baik & 6 & 17,1 \\
\hline \multicolumn{1}{c}{ Jumlah } & $\mathbf{3 5}$ & $\mathbf{1 0 0}$ \\
\hline
\end{tabular}

Dari tabel 1 menunjukan lebih dari sebagian responden memiliki pengetahuan cukup sebanyak 24 orang $(68,6 \%)$.

2) Persepsi Ibu Hamil

Tabel 2 Distribusi Responden Berdasarkan Persepsi Ibu Hamil Di Wilayah Kerja Puskesmas Tikung Tahun 2019.

\begin{tabular}{ccc}
\hline Persepsi & Jumlah & $(\%)$ \\
\hline Persepsi positif & 28 & 80,0 \\
Persepsi negative & 7 & 20.0 \\
\hline Jumlah & $\mathbf{3 5}$ & $\mathbf{1 0 0}$ \\
\hline Dari tabel 2 & menunjukan & bahwa
\end{tabular}
sebagian responden sebanyak 28 orang $(80,0 \%)$ memiliki persepsi positif.

3) Kunjungan $\mathrm{K} 1$

Tabel 3 Distribusi Responden Berdasarkan Kunjungan K1 Ibu Hamil Di Wilayah Kerja Puskesmas Tikung Tahun 2019

\begin{tabular}{|c|c|c|}
\hline Persepsi & Jumlah & $(\%)$ \\
\hline $\begin{array}{ll}\text { Tidak } & \text { melakukan } \\
\text { kunjungan } & \end{array}$ & 6 & 17,1 \\
\hline Melakukan kunjungan & 29 & 82,9 \\
\hline
\end{tabular}

Berdasarkan tabel 8 menunjukan bahwa sebagian besar responden sebanyak 29 orang $(82,9 \%)$ melakukan kunjungan K1.

4) Hubungan Pengetahuan dengan Kunjungan K1.

Tabel 4 Tabulasi Silang Hubungan Pengetahuan Ibu Hamil Dengan Kunjungan K1 Di Wilayah Kerja Puskesmas Tikung Kabupaten Lamongan 2019.

Dari tabel 4 diatas menunjukkan bahwa responden yang mempunyai pengetahuan baik seluruhnya melakukan kunjungan K1 (100\%), sedangkan ibu hamil yang memiliki pengetahuan cukup sebagian besar melakukan kunjungan K1 (79,3\%), namum ibu hamil yang pengetahuannya kurang seluruhnya tidak melakukan kunjungan K1. Kesimpulannya semakin baik pengetahuan ibu maka kecenderungan untuk melakukan kunjungan $\mathrm{K} 1$ semakin besar. Hal ini dibuktikan dengan menggunakan uji spearman rank dengan bantuan spss versi 16 didapatkan nilai, dimana (rs) 0,692 dan $r$ tabel 0,2746 dengan tingkat signifikan $0,000(\mathrm{p}<0,05)$. $\mathrm{H} 0$ ditolak $\mathrm{H} 1$ diterima artinya ada hubungan antara variabel pengetahuan dengan kunjungan K1 di wilayah kerja Puskesmas Tikung Kabupaten Lamongan 2019

5) Hubungan persepsi dengan kunjungan K1 
Tabel 5 Tabulasi Silang Hubungan Persepsi Ibu Hamil Dengan Kunjungan K1 di Wilayah Kerja Puskesmas Tikung Kabupaten Lamongan 2019.

\begin{tabular}{lcc}
\hline Kunjungan K1 & $\begin{array}{c}\text { Persepsi } \\
\text { Negatif }\end{array}$ & $\begin{array}{c}\text { Persepsi } \\
\text { Positif }\end{array}$ \\
\hline Tidak melakukan & $66,7 \%$ & $33,3 \%$ \\
Melakukan & $10,3 \%$ & $89,7 \%$ \\
\hline
\end{tabular}

Dari tabel 5 diatas menunjukkan bahwa ibu hamil yang mempunyai persepsi positif sebanyak $26(89,7 \%)$ yang melakukan kunjungan $\mathrm{K} 1$ dan 3 (33,3\%) tidak melakukan kunjungan k1, sedangkan ibu hamil yang mempunyai persepsi negatif sebanyak $4(66,7 \%)$, dan yang tidak melalukan kunjungan K1 sebanyak 2 $(10,3 \%)$ ibu hamil melakukan kunjungan K1. Kesimpulannya semakin pesepsi ibu hamil positif maka kecenderungan untuk melakukan kunjungan K1 semakin besar. Berdasarkan hasil penelitian dengan menggunakan uji spearman rank dengan bantuan spss vers 16 didapatkan nilai, dimana (rs) 0,531 dan $r$ tabel 0,2746 dengan tingkat signifikan $0,001(\mathrm{p}<0,05)$. $\mathrm{H} 0$ ditolak $\mathrm{H} 1$ diterima artinya ada hubungan antara variabel persepsi dengan kunjungan K1 di wilayah kerja Puskesmas Tikung Kabupaten Lamongan 2019

\section{PEMBAHASAN}

\section{1) Pengetahuan Ibu Hamil}

Dari hasil analisis pada tabel pengetahuan diketahui di wilayah kerja Puskesmas Tikung Kabupaten Lamongan tahun 2019 lebih dari sebagian besar ibu hamil sebanyak $(68,6 \%)$ yang mempunyai pengetahuan cukup tentang kunjungan $\mathrm{K} 1$.

Faktor yang mempengaruhi pengetahuan ibu hamil diantaranya pendidikan. Berdasarkan table 4.2 diketahui bahwa sebagian besar dari ibu hamil berpendidikan SMA. Pengetahuan merupakan hasil tahu dan ini terjadi setelah orang mengadakan penginderaan terhadap obyek tertentu. Penginderaan terhadap obyek terjadi melalui panca indera manusia yakni, penglihatan, pendengaran, penciuman, rasa dan raba dengan sendiri. Notoatmodjo (2010)

\section{2) Persepsi Ibu Hamil}

Dari hasil analisis pada tabel persepsi diketahui sebagian besar ibu hamil sebanyak $(80,0 \%)$ yang mempunyai persepsi positif melakukan kunjungan K1 .

Ada 2 Faktor yang mempengaruhi persepsi ibu hamil yaitu Faktor eksternal (objeknya) sedangkan faktor internal (orang yang mempersepsikan stimulus tersebut). Factor internal salah satunya ada keinginan atau harapan yaitu ibu hamil yang memiliki harapan terhadap kondisi kehamilannya, yaitu kesehatan ibu dan janinnya yang optimal cenderung akan memiliki persepsi positif. Selain harapan bisa karna pengalaman, ibu hamil yang memiliki pengalaman pada hasil sebelumnya dan melakukan kunjungan K1dimana kehamilannya berakhir dengan kondisi optimal, maka memiliki kecenderungan berpersepsi positif terhadap kunjungan $\mathrm{K} 1$. Berdasarkan table 4.5 mayoritas ibu hamil yang ke 2 atau lebih . hal ini menunjukan bahwa lebih memiliki pengalaman mengenai kunjungan K1.

\section{3) Kunjungan K1}

Dari hasil analisis pada tabel kunjungan diketahui sebagian besar ibu hamil sebanyak $(82,9 \%)$ melakukan kunjungan K1.

Menurut Lawrence Green dalam Notoatmodjo (2010), perilaku seseorang atau masyarakat tentang kesehatan ditentukan oleh pengetahuan, sikap, kepercayaan, tradisi, dan atau masyarakat bersangkutan. Disamping itu, ketersediaan fasilitas, sikap, dan perilaku para petugas kesehatan juga akan mendukung dan memperkuatan terbentuknya perilaku. Seorang ibu hamil yang tidak mau memeriksan kehamilan bagi ibu dan janin yang dikandung. Tetapi barangkali juga karena rumahnya jauh dari puskesmas tempat memeriksakan kehamilannya atau peralatan yang tidak lengkap. Sebab lain mungkin karena para petugas kesehatan atau tokoh masyarakat lain disekitarnya 
tidak pernah memberikan contoh / penyuluhan tentng pentingnya pemeriksaan kehamilan. Perilaku mencakup 3 domain, yakni: pengetahuan (knowledge), sikap (attitude) dan tindakan atau praktik (health knowledge). Kunjungan k1 diwilayah kerja UPT puskesmas Tikung yang dipengerahui factor pengetahuan, dukungan keluarga, dan tenaga kesehatan. Seperti halnya pendidikan ibu hamil semakin tinggi pendidikan ibu hamil semakin baik pula pengetahuan akan pentingnya kunjungan K1. Dukungan keluarga saat saya melakukan kunjungan, keluarga sangat mendukung adanya kunjungan $\mathrm{K} 1$ akan halnya keluarga menginginkan ibu dan bayi sehat, dan pelayanan kesehatan dimana kader mengadakan penyuluhan untuk para cpw mengenai kunjungan K1. Menurut Adicondro, N. \& Purnamasari. A. (2011) Dukungan keluaraga adalah peran yang sangat penting sebagai penentu sikap ibu hamil. Karena itu melalui keluarga seorang ibu hamil lebih sadar akan pentingnya dirinya dan janinnya bagi keluarga, sehingga mendorong untuk melakukan kunjungan $\mathrm{K} 1$

\section{4) Hubungan Pengetahuan Ibu Hamil Dengan Kunjungan K1 Di Wilayah Kerja Puskesmas Tikung Kabupaten Lamongan 2019.}

Dari tabel 4 dapat diketahui bahwa responden mempunyai pengetahuan baik seluruhnya melakukan kunjungan $\mathrm{K} 1$ sebesar (100\%), sedangkan ibu hamil yang memiliki pengetahuan cukup sebagian besar melakukan kunjungan K1 sebersar (79,3\%), namum ibu hamil yang pengetahuannya kurang seluruhnya tidak melakukan kunjungan K1.

Bedasarkan hasil penelitian dengan menggunakan uji spearman rank dengan bantuan SPSS for windows antara pengetahuan ibu hamil dengan kunjungan $\mathrm{K} 1$, didapatkan nilai koefisiensi korelasi Spearmen's rho $=0,730$ dan nilai sig. 2 tailed $(\mathrm{p})=0,01$ dimana $\mathrm{p}<0,005$ sehingga H0 ditolak H1 diterima, artinya Ada
Hubungan pengetahuan ibu hamil dengan kunjungan K1. Kesimpulannya semakin baik pengetahuan ibu hamil maka kecenderungan untuk melakukan kunjungan K1 semakin besar.

Ibu hamil yang memiliki pengetahuan baik dapat lebih mudah untuk menagkap informasi dan memiliki kecendurungan untuk melakukan kunjungan K1 dikarenakan ibu mengetahui pentingnya untuk melakukan kunjungan K1 bagi ibu dan calon bayinya. Hal tersebut akan mendorong ibu hamil untuk melakukan Kunjungan K1.

Sesuai dengan pendapat Notoatmodjo (2010) bahwa pengetahuan dapat menjadi dominan yang sangat penting bagi terbentuknya perilaku atau tindakan seseorang. Berdasarkan teori diatas, responden yang memiliki pengetahuan yang baik tentang kunjungan K1 akan membentuk sikap dan perilaku yang positif untuk kunjungan $\mathrm{K} 1$. Hal ini dibuktikan dan diteliti oleh Febrianti \& Susilawati (2012) yang mengatakan adanya hubungan pengetahuan dengan perilaku kunjungan kehamilan $(\mathrm{p}<0,05)$.

\section{5) Hubungan Persepsi Ibu Hamil Dengan Kunjungan K1 Di wilayah Puskesmas Tikung Lamongan 2019.}

Berdasarkan tabel 4.10 menjelaskan bahwa ibu hamil yang mempunyai persepsi positif sebanyak $(92,9 \%)$ melakukan kunjungan $\mathrm{K} 1$ dan $(7,1 \%)$ tidak melakukan kunjungan $\mathrm{k} 1$, sedangkan ibu hamil sebanyak $(57,1, \%)$ mempunyai persepsi negative tidak melalukan kunjungan K1 dan banyak $(42,9 \%)$ ibu hamil melakukan kunjungan $\mathrm{K} 1$.

Berdasarkan hasil penelitian dengan menggunakan uji spearman rank dengan bantuan SPSS for windows antara persepsi ibu hamil dengan kunjungan $\mathrm{K} 1$, didapatkan nilai koefisiensi korelasi Spearmen's rho $=0,531$ dan nilai sig. 2 tailed $(\mathrm{p})=0,05$ dimana $\mathrm{p}<0,005$ sehingga H0 ditolak H1 diterima, artinya Ada 
Hubungan persepsi ibu hamil dengan kunjungan K1. Kesimpulnya semakin persepsi ibu hamil positif maka kecendurungan untuk melakukan kunjungan $\mathrm{K} 1$ semakin besar.

Menurut Bimo Walgito (2009) bahwa persepsi merupakan suatu proses pengorganisian, penginterpresian terhadap stimulus yang diteriam oleh individu sehingga menjadi suatu yang berarti. Hal tersebut berdasarkan perasaan kemampuan berpikir, pengalaman-pengalaman yang dimiliki individu yang tidak sama.

Hal ini dapat diartikan bahwa ibu hamil yang memiliki persepsi positif tentang kunjungan $\mathrm{K} 1$ akan cenderung untuk menerapakan persepsinya tersebut kedalam suatu tindakan yang berarti positif yaitu kedalam kunjungan K1. Demikian pula sebaliknya.

\section{KESIMPULAN DAN SARAN}

1) Kesimpulan

Berdasarkan penelitian yang dilakukan di Wilayah Kerja Puskesmas Tikung Lamongan tahun 2019 maka kesimpulan dari penelitian ini adalah :

(1) Sebagian besar ibu hamil memiliki pengetahuan cukup di wilayah kerja Puskesmas Tikung Kabupaten Lamongan tahun 2019.

(2) Sebagian besar ibu hamil memiliki persepsi negative di wilayah kerja Puskesmas Tikung Kabupaten Lamongan tahun 2019.

(3) Terdapat hubungan pengetahuan dan persepsi dengan kunjungan $\mathrm{K} 1$ di wilayah kerja Puskesmas Tikung Kabupaten Lamongan tahun 2019.

2) Saran

Diharapkan Hasil penelitian ini dapat digunakan sebagai masukan untuk pertimbangan dan informasi dalam pengetahuan dan persepsi ibu hamil dengan kunjungan $\mathrm{K} 1$

Diharapkan untuk tenaga kesehatan memberikan pelyanan konseling tentang pentingnya kunjungan K1 bagi ibu hamil.
Bagi peneliti selanjutnya hasil penelitian ini dapat digunakan sebagai studi pendahuluan atau sebagai acuan pelaksanaan peneliti yang akan dating sehingga diharapkan akan dapat dicapai hasil yang lebih baik untuk melengkapi segala kekurangan yang ada di dalam penelitian ini, serta diharapkan menambah variable-variabel lain atau faktor-faktor lain yang berhubungan dengan kunjungan $\mathrm{K} 1$ bagi ibu hamil

\section{DAFTAR PUSTAKA}

Adicondro, N. \$ Purnamasari. A. 2011. Dukungan Sosial Keluarga Dan Self Regulation learing. Yogyakarta

Azwar A \& Joedeprihartono, 2014. Metodelogi Penelitian Kedokteran Kesehatan Masyarakat.Tangerang

Bimo Walgito. 2010. Pengantar Psikologi Umum. Yogyakarta

Departermen Kesehatan RI. 2010. Pedoman Pelayanan Antenatel. Depkes RI. Jakarta

Hidayat, 2010. Metode Penelitian Keperawatan Dan Teknik Analisis Data. Jakarta.

Kementerian Kesehatan RI. 2010. Pedoman Pelayanan Antenatal Terpadu. Kemenkes RI. Jakarta

Machfoedz. 2009. Metodologi Penelitian Bidang Kesehatan. Keperawatandan Kebidanan. Yogyakarta.

Marmi, 2011. Asuhan Kebidanan pada Masa Antenatal. Yogyakarta: Pustaka Pelajar

Niken Kurnia Febyanti \& Dwi Susilawati. 2012. Hubungan Pengetahuan Ibu Hamil Tentang Antenatal Care 
Terhadap Perilaku Kunjungan Kehamilan.

Notoadmodjo, S. 2010. Promosi Kesehatan dan Ilmu Perilaku. Jakarta : Renika Cipta.

Notoadmodjo, S. 2012. Pendidikan dan Perilaku Kesehatan. Rineka Cipta. Jakarta.

Notoatmodjo, S. 2010. Ilmu Perilaku Kesehatan. Jakarta: Rineka Cipta

Nursalam, 2014. Konsep Dan Penerapan Metodelogi Penelitian Ilmu Keperawatan . Jakarta.

Pujiyanto. 2013. Iklan Layanan Masyarakat. Yogyakarta: Andi

Purwaningsih, W \& Siti Fatmawati. 2010. Asuhan Keperawatan Maternitas. Yogyakarta: Nuhu Medika.
Robbins. Stephen P. 2003. Organizational Behavior. Jakarta

Rukiah , A Y., Yulianti L, 2013. Asuhan Kebidanan Kehamilan. Jakarta

Saifuddin, AB. 2009. Paduan Praktis Pelayanan Kesehatan Maternal dan Neonatal. Jakarta : EGC

Setiadi 2013. Konsep dan Praktek Penulisan Riset Keperawatan, Edisi 2. Yogyakarta.

Suranto, 2010. Komunikasi Sosial Budaya.Graha Ilmu, Yogyakarta.

Wagiyo, Ns, Putramto. 2016. Asuhan Keperawatan Antenatal, Intranatal \& Bayi Lahir Fisiologis dan Patologis. Yogyakarta

Widayatun. 2009. Perilaku Organisasi Konsep Dasar dan Aplikasinya. Jakarta: PT Raja Grafindo Persada 